\title{
PROBLEMATIKA GURU DALAM MENYUSUN RENCANA PELAKSANAAN PEMBELAJARAN TEMATIK TERPADU : STUDI KASUS SD INPRES 48 INGGRAMUI MANOKWARI
}

\author{
BERTHA DIMARA \\ SD Inpres 42 Taman Ria Manokwari Provinsi Papua Barat \\ Email: berhadimara024@gmail.com
}

\begin{abstract}
ABSTRAK
Problematika Guru Dalam Menyusun RPP Tematik Terpadu di SD Inpres 48 Inggramui Distrik Manokwari Barat Provinsi Papua Barat Tahun 2022. Penelitian ini bertujuan untuk menganalisis kesulitan guru dalam menyusun RPP tematik terpadu,faktor penghambat serta upaya yang dilakukan untuk mengatasi kesulitan guru dalam menyusun RPP tematik terpadu.Pendekatan yang digunakan adalah deskriptif kualitatif rancangan studi kasus tunggal. Sumber data adalah data primer yang diperoleh dari Kepala sekolah, pengawas sekolah dan guru. Data sekunder diperoleh dari hasil pengamatan dan pengecekan dokumen yang relevan dengan penelitian seperti silabus, RPP dan jurnal guru. Teknik pengumpulan data melalui wawancara, observasi dan dokumentasi. Keabsahan data menggunakan uji kredibilitas dan validitas data yaitu triangulasi sumber, teknik dan bahan refernsi. Analisis data menggunakan analisis data Model Milles dan Huberman yaitu melalui pengecekan data, reduksi data, display data, verifikasi data. Hasil penelitian menunjukkan bahwa guru kesulitan dalam:(1) mengembangkan indikator pembelajaran,(2) merumuskan tujuan pembelajaran, (3) menentukan model dan metode pembelajaran,(4) menentukan sumber dan media pembelajaran, (5) menyusun langkah-langkah pembelajaran, (6) membuat dan mengembangkan penilaian autentik. Faktor penghambat yang mempengaruhi guru dalam Menyusun RPP tematik terpadu adalah minimnya ; (1) pemahaman guru dalam penyusunan RPP tematik terpadu, (2) pelatihan penyusunan RPP tematik terpadu, (3) ketersediaan waktu, (4) sarana penunjang pembelajaran, (5) motivasi dan komitmen guru dalam menngembangkan potensi diri, (6) kemampuan memanfaatkan teknologi. Upaya yang dilakukan guru agar keluar dari kesulitan ini adalah: (1) guru aktif mencari informasi dari berbagai media, tidak harus mengikuti pelatihan, (2) kolaborasi kepala sekolah dan pengawas lebih diintensifkan, (3) guru harus memiliki motivasi dan komitmen yang tinggi, (4) kemampuan IT guru harus baik agar meringankan pekerjaan guru. Beberapa guru menunjukkan progress yang baik dibeberapa komponen RPP, yang lainnya masih membutuhkan bimbingan lebih lanjut.
\end{abstract}

Kata Kunci : Problematika, RPP tematik terpadu

\section{ABSTRACT}

Teacher Problems in Developing Integrated Thematic RPP at SD Inpres 48 Inggramui West Manokwari District, West Papua Province in 2022. This study aims to analyze the difficulties of teachers in preparing integrated thematic RPP, inhibiting factors and efforts made to overcome teacher difficulties in compiling thematic RPP integrated approach. The approach used is descriptive qualitative single case study design. Sources of data are primary data obtained from school principals, school supervisors and teachers. Secondary data were obtained from observations and checking of documents relevant to the study such as syllabus, lesson plans and teacher journals. Data collection techniques through interviews, observation and documentation. The validity of the data used a credibility of test and validity data, namely triangulation of sources, techniques and reference materials. Data analysis uses data analysis of Milles and Huberman models, namely through data checking, data reduction, data display, and data verification. The results showed that teachers had difficulties in: (1) developing learning indicators, (2) formulating learning objectives, (3) determining learning models and methods, 4) determining learning resources and media, (5) compiling learning steps, (6) create and develop authentic assessments. Inhibiting factors that influence teachers in preparing integrated 
thematic lesson plans are the lack of; (1) understanding of teachers in the preparation of integrated thematic lesson plans, (2) training in the preparation of integrated thematic lesson plans, (3) availability of time, (4) learning support facilities, (5) motivation and commitment of teachers in developing self-potential, (6) ability to utilize technology. Efforts made by teachers to get out of this difficulty are: (1) teachers actively seek information on various media, do not have to attend training, (2) collaboration between principals and supervisors is intensified, (3) teachers must have high motivation and commitment, (4) the teacher's IT skills must be good in order to ease the teacher's work. Some teachers show good progress in several components of the lesson plan, others still need further guidance.

Keywords: Problematics, integrated thematic lesson plans

\section{PENDAHULUAN}

Kompetensi pedagogik merupakan salah satu kompetensi yang berkaitan langsung dengan pengelolaan pembelajaran di kelas. Dalam mengelola pembelajaran guru wajib menguasai dan memahami aspek-aspek yang terkandung dalam kompetensi pedagogik guru. Terdapat 7 aspek yang harus dikuasai guru sebelum melaksanakan pembelajaran di kelas, diantaranya adalah memahami karateristik peserta didik, memahami teori belajar dan prinsip pembelajaran yang mendidik, mampu mengembangkan kurikulum, menciptakan pembelajaran yang mendidik, membangun komunikasi yang efektif dengan peserta didik, membantu peserta didik mengembangkan potensi dalam diri serta mampu melakukan evaluasi dan penilaian secara tepat dan menggunakan hasilnya untuk merancang kegiatan pembelajaran selanjutnya.

Kompetensi ini menjadi modal utama guru dalam menciptakan pembelajaran yang interaktif, inspiratif, menyenangkan, menantang, memotivasi peserta didik untuk berpartisipasi aktif, serta memberikan ruang yang cukup bagi prakarsa, kreativitas, dan kemandirian sesuai dengan bakat, minat, dan perkembangan fisik serta psikologis peserta didik (PP Nomor 19 Tahun 2005 Pasal 19 butir 1). Berbekal kompetensi ini diharapkan guru mampu menyusun dan merancang perangkat pembelajaran yang berkualitas sehingga dapat memberikan kontribusi positif terhadap proses belajar peserta didik dan memudahkan guru untuk mencapai tujuan pembelajaran yang diharapkan.

Upaya peningkatan kualitas pembelajaran adalah dengan merancang perangkat pembelajaran yang berkualitas. Perancangan pembelajaran turut mempengaruhi berkualitas atau tidaknya proses pembelajaran yang dikelola guru. Perangkat pembelajaran sebaiknya disiapkan guru sebelum melakukan aktivitas belajar mengajar. Menurut Jamil (2013: 131) "Perangkat pembelajaran merupakan segala sesuatu yang dipersiapkan guru sebelum melaksanakan kegiatan proses pembelajaran". Hal senada disampaikan juga oleh Fathurrohman (2012: 203) yang menjelaskan bahwa pada dasarnya perangkat pembelajaran mempunyai fungsi untuk mempermudah guru dalam melaksanakan atau mengelola kegiatan pembelajaran yang ada di kelas. Perangkat pembelajaran menurut Permendikbud Nomor 22 Tahun 2016 Bab III meliputi silabus, RPP, bahan ajar, media pembelajaran, sumber belajar dan penilaian pembelajaran.

Mengacu pada Permendikbud Nomor 81 A Tahun 2013 Tentang Implementasi Kurikulum bahwa guru wajib menyusun rencana pembelajaran sebelum melakukan pembelajran di kelas, sayangnya tidak semua guru menyadari akan hal ini, sehingga pembelajaran yang dikelolanya berjalan tanpa makna. Berbagai upaya dilakukan sekolah untuk membantu guru meningkatkan kompetensinya dengan mengikutsertakan guru dalam berbagai kegiatan pelatihan, workshop, diklat yang dilakukan pemerintah bahkan pembinaan melalui kegiatan Kelompok Kerja Guru (KKG) gugus dan supervisi oleh kepala sekolah, agar dapat meningkatkan kompetensinya dalam menyusun RPP, namun semua usaha ini belum menujukkan hasil yang menggembirakan,

Guru sebagai ujung tombak transformasi pendidikan diharapkan mampu beradaptasi dengan setiap perubahan. Perubahan sistem pendidikan yang terjadi salah satunya adalah perubahan kurikulum dimana dalam pelaksanaan pembelajaran kurikulum 2013 
diselenggarakan secara tematik terpadu termasuk dalam penyusunan perangkat pembelajaran (RPP). Temuan di lapangan terdapat beberapa kelemahan guru dalam menyusun rencana pelaksanaan pembelajaran (RPP). Minimnya pemahaman serta rendahnya motivasi diri disinyalir menjadi pemicu guru mengambil jalan pintas dengan mengadopsi rencana pelaksanaan pembelajaran (RPP) yang sudah tersedia di internet. Bahkan terkadang guru mengajar tanpa RPP. Kondisi ini berimplikasi pada proses pembelajaran yang konvensional.Guru menyiapkan RPP hanya sebatas tututan administrasi sekolah, itupun RPP yang dimiliki guru hasil duplikasi dari internet atau dari teman lain.

Penelitian sebelumnya yang dilakukan oleh oleh Suraji, Wamugi dan Nurhamidi (dalam Mawardi, 2019:70) yang menemukan bahwa, masih banyak guru yang belum mampu menyusun perangkat pembelajaran sendiri, kebanyakan bersikap pragmatis, diantaranya dengan mengkopi rencana pelaksanaan pembelajaran yang sudah jadi. Penelitian lainnya yang dilakukan oleh Kinarsih (dalam Mawardi, 2019:71) juga mengungkapkan temuan yang sama bahwa, dalam penyusunan perangkat pembelajaran, masih ada guru yang hanya menduplikasi RPP karya orang lain. Penelitian yang dilakukan kali ini menggunakan rancangan studi kasus tunggal dimana fenomena di sekolah tempat peneliti melakukan penelitian para guru sudah mengerti dengan baik pentingnya RPP bagi seorang guru, namun dalam mengembangkan komponen-komponen RPP seperti mengembangkan indikator, tujuan pembelajaran, menentukan materi ajar, menyiapkan media pembelajaran, strategi atau metode dan penilaian pembelajaran masih perlu dibenahi melalui supervisi baik oleh kepala sekolah maupun pengawas sekolah ataupun melalui kegiatan kelompok kerja guru di sekolah (KKG mini).Penelitian ini mengutamakan proses dari pada hasil sehingga tidak melalui tahapan siklus.

Kesulitan guru dalam mengembangkan komponen-komponen RPP bukan karena guru tidak mampu tetapi lebih disebabkan oleh karena guru tidak mau berupaya untuk mengembangkan kompetensinya dalam penyusunan RPP secara mandiri. Kondisi yang demikian tidak boleh diabaikan begitu saja, karena berimbas pada rendahnya kualitas pembelajaran di sekolah. Rencana Pelaksanaan Pembelajaran (RPP) menjadi landasan berpijaknya guru dalam menerapkan pembelajaran di kelas. Semakin baik RPP yang dibuat semakin baik pula proses belajar mengajar yang diramu guru. Rencana pelaksanaan pembelajaran yang di susun dengan tingkat akurasi yang tinggi turut mempengaruhui keefektifan pembelajaran sehingga mampu meningkatkan mutu pembelajaran yang dikemas guru.

Fenomena di atas dan fakta dilapangan, menjadi rujukan bagi peneliti untuk melakukan penelitian Tindakan Studi Kasus di SD Inpres 48 Inggramui Kabupaten Manokwari Provinsi Papua Barat dengan judul " Problematika Guru Dalam Menyusun Rencana Pelaksanaan Pembelajaran Tematik Terpadu". Tujuan dari penelitian ini adalah untuk: (1) menganalisis upaya yang dilakukan untuk mengatasi kesulitan guru dalam menyusun RPP tematik terpadu; (2) menganalisis faktor penghambat guru dalam menyusun RPP tematik terpadu; Berdasarkan latar belakang dan tujuan penelitian ini, maka dapat dirumuskan rumusan masalah pada penelitian antara lain: (1) Bagaimana upaya yang dilakukan untuk mengatasi kesulitan guru dalam menyusun RPP tematik terpadu? (2) Faktor apa saja yang menjadi menghambat guru dalam menyusun RPP tematik terpadu?

\section{METODE PENELITIAN}

Penelitian ini dilakukan di SD Inpres 48 Inggramui Manokwari Barat Kabupaten Manokwari Provinsi Papua Barat. Sabagai informan dalam penelitian ini adalah kepala sekolah, 6 guru kelas, 1 guru pendidikan agam Kristen dan 1 guru olah raga serta perwakilan peserta didik kelas 4,5,dan 6 masing-masing 1 orang. Penelitian ini adalah penilitian kualitatif deskriptif dengan rancangan studi kasus tunggal. Penelitian ini lebih mengutamakan proses dari pada hasil. Penelitian deskriptif kualitatif digunakan untuk meneliti pada kondisi obyek yang alamiah dan sesuai fakta dilapangan. Penelitian deskriptif kualitatif lebih menekankan makna daripada generalisasi.Analisis datanya bersifat induktif. Teknik pengumpulan data dilakukan 
melalui wawancara semiterstruktur, observasi dan dokumentasi. Wawancara kepala sekolah, guru dan peserta didik menggunakan pedoman wawancara yang telah disusun secara sistematis oleh peneliti. Observasi menggunakan lembar telaah RPP dan catatan lapangan terkait focus penelitian dan dokumentasi lebih kepada foto-foto kegiatan sekolah.

Sumber data dalam penelitian ini berasal dari dari data primer dan sekunder. Data primer diperoleh dari hasil wawancara dengan kepala sekolah, guru dan perwakilan peserta didik. Data sekunder diperoleh dari hasil observasi terhadap dokumen yang relevan dengan penelitian seperti dukumen silabus, RPP, jurnal belajar guru dan dokumen lain yang relevan serta fotofoto kegiatan (dokumentasi). Uji keabsahan data pada penelitian ini menggunakan uji validitas dan reliabilitas triangulasi sumber, teknik, dan bahan referensi. Triangulasi sumber yaitu kepala sekolah, pengawas, guru dan peserta didik. Triangulasi teknik pengumpulan data melalui wawancara, observasi dan dokumentasi. Bahan referensi melalui pengecekan dokumen yang relevan dengan penelitian.

Teknik analisis data pada penelitian ini menggunakan model interaktif Miles and huberman meliputi pengumpulan data (data colellection), reduksi data (data reduction), penyajian data (data display) dan penarikan kesimpulan (conclusion drawing/verivication). Langkah-langkah analisis yaitu: pengumpulan data (data collection) merupakan suatu proses pengumpulan data atau informasi yang diperoleh melalui wawancara, observasi dan dokumentasi dari informan mengenai variabel-variabel yang diteliti. Dilanjutkan dengan melakukan analisis data yaitu Reduksi data (data reduction). Reduksi data adalah proses menganalisis data dengan cara melakukan pemilihan data, memfokuskan, menyederhanakan, mengabstraksikan, dan mentransformasikan data hingga datanya menjadi jenuh.Data ini kemudian disajikan dalam bentuk teks narasi, matrik, tabel. Grafik atau bagan display data.Tahapan terakhir adalah penarikan kesimpulan. Penarikan kesimpulan dilakukan setelah data direduksi dan display dalam berbagai bentuk untuk memberikan gambaran secara jelas tentang fokus penelitian (Sugiyono, 2016:338)

\section{HASIL DAN PEMBAHASAN}

\section{Hasil}

Berdasarkan hasil studi awal yang dilakukan melalui wawancara dengan kepala sekolah, pengawas, guru, dan didukung oleh hasil observasi dan pengecakan dokumen yang dilakukan peneliti di SD Inpres 48 Inggramui Manokwari Barat Kabupaten Manokwari Provinsi Papua Barat pada tanggal 10 Januari sampai dengan 31 Januari 2022, ditemukan fakta bahwa dalam menyusun RPP tematik terpadu sebagian besar guru mengalami kesulitan dalam menjabarkan setiap komponen RPP Tematik Terpadu dalam silabus maupun RPP. Probelamatika guru dalam menyusun RPP Tematik terpadu tidak terlepas dari faktor penghambat baik faktor internal maupun eksternal yang berdampak pada rendahnya kompetensi guru dalam menyusun RPP tematik terpadu. Untuk mengatasi problematika guru ini, beberapa upaya disarankan untuk dilakukan guru agar dapat keluar dari masalah yang dihadapi. Data yang diperoleh dari hasil wawancara, observasi dan pengecekan dokumen yang telah dikumpulkan dan dianalisis, disajikan hasilnya dalam tabel berikut ini:

Tabel 1. Kondisi awal kemampuan guru dalam menyusun RPP tematik terpadu

\begin{tabular}{|l|l|c|l|}
\hline No & Komponen RPP & Jumlah Guru & Hasil penelitian awal \\
\hline 1 & $\begin{array}{l}\text { Pengembangan indikator } \\
\text { Pembelajaran }\end{array}$ & 8 & $\begin{array}{l}\text { Belum dapat menyusun RPP sendiri. Masih } \\
\text { mengadopsi dari internet }\end{array}$ \\
\hline 2 & Perumusan Tujuan Pembelajaran & 8 & $\begin{array}{l}\text { Belum paham merumuskan tujuan pembelajaran } \\
\text { mencakup 4 unsur ABCD. Yang nampak baru 2 } \\
\text { unsur yaitu AB }\end{array}$ \\
\hline 3 & $\begin{array}{l}\text { Penentuan Metode dan Model } \\
\text { pembelajaran }\end{array}$ & 8 & $\begin{array}{l}\text { Metode sudah bervariasi namun tidak pada } \\
\text { model pembelajaran }\end{array}$ \\
\hline
\end{tabular}




\begin{tabular}{|l|l|c|l|}
\hline 4 & Langkah Pembelajaran & 8 & $\begin{array}{l}\text { Keluhan guru pada penerapan pendekatan } \\
\text { saintifik serta cara mengaitkan materi yang satu } \\
\text { dengan yang lain. }\end{array}$ \\
\hline 5 & Sumber dan Media Pembelajaran & 8 & $\begin{array}{l}\text { Buku menjadi satu-satunya sumber belajar. } \\
\text { Media masih terabaikan. }\end{array}$ \\
\hline 6 & Penialaian autentik & 8 & $\begin{array}{l}\text { Dominan penilaian pengetahuan. Keterampilan } \\
\text { sesekali dan sikap belum tersentuh. Guru } \\
\text { kesulitan menentukan aspek dan rubriknya. }\end{array}$ \\
\hline
\end{tabular}

Agar lebih mudah memahaminya data di atas dapat disajikan dalam diagram berikut ini :

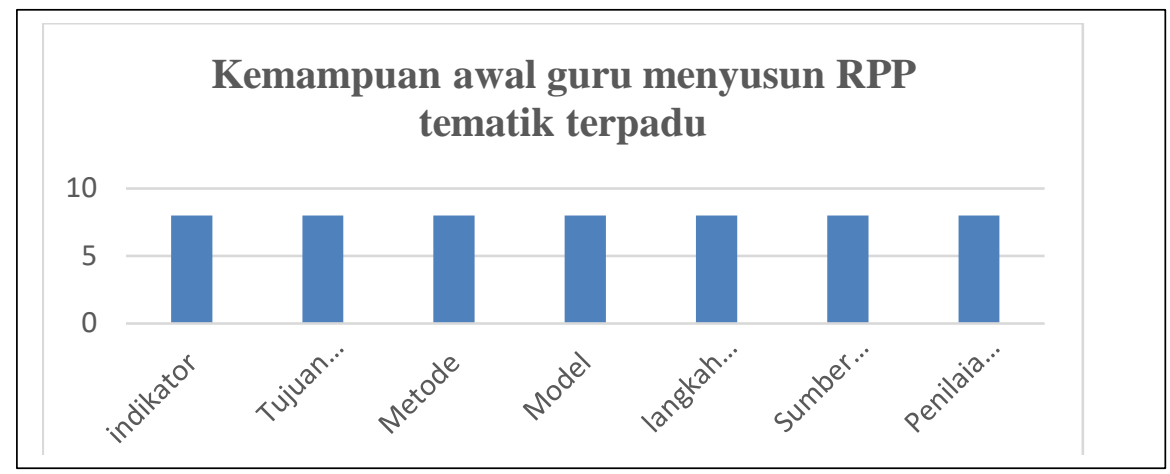

\section{Gambar 1: Grafik Kemampuan awal guru dalam menyusun RPP tematik terpadu}

Data di atas menggambarkan kondisi awal guru saat penelitian dilakukan terhadap 8 guru di SD Inpres 48 Inggramui Distrik Manokwari Barat. Sebagaimana telah dipaparkan sebelumnya bahwa untuk menyusun RPP tematik terpadu guru mengalami kesulitan, sehingga mereka lebih memilih untuk mengadopsi dari internet atau buku tanpa mengadaptasi terlebih dahulu sebelum mengimplementasikan dalam pembelajaran sehingga dalam penerapannya tidak sesuai dengan kondisi sekolah dan karateristik peserta didik. Dari kondisi awal ini peneliti sebagai kepala sekolah yang memiliki kemampuan dalam menyusun RPP tematik terpadu mencoba berbagi ilmu dengan guru-guru SD Inpres 48 Inggramui Distrik Manokwari Barat yang dilakukan mulai $10-31$ Januari 2022. Selama penelitian dilakukan, peneliti sebagai instumen kunci mengumpulkan data melalui wawancara atau diskusi selama pembimbingan, melakukan observasi dan pengecekan dokumen. Data-data tersebut kemudian di reduksi dan di display dan selanjutnya ditarik kesimpulan. Display data selama penelitian tersaji pada tabel berikut:

Tabel 1. Kemampuan guru dalam menyusun rpp tematik terpadu selama penelitian

\begin{tabular}{|l|l|c|l|}
\hline No & Komponen RPP & Jumlah Guru & Hasil selama penelitian \\
\hline 1 & $\begin{array}{l}\text { Pengembangan indikator } \\
\text { Pembelajaran }\end{array}$ & 8 & $\begin{array}{l}5 \text { guru sudah dapat menentukan indikator } \\
\text { menggunakan KKO secara berurtan dari yang } \\
\text { mudah ke sulit menyusun RPP sendiri karena } \\
\text { belum dapat mengembangkan indikator (masih } \\
\text { duplikasi). 3 guru perlu bimbingan }\end{array}$ \\
\hline 2 & Perumusan Tujuan Pembelajaran & 8 & $\begin{array}{l}5 \text { guru sudah dapat merumuskan tujuan } \\
\text { pembelajaran mencakup 4 unsur ABCD. }\end{array}$ \\
\hline 3 & $\begin{array}{l}\text { Penentuan Metode dan Model } \\
\text { pembelajaran }\end{array}$ & 8 & $\begin{array}{l}8 \text { guru sudah menggunakan metode sudah } \\
\text { bervariasi.2 guru dapat menerapakna model } \\
\text { pembelajaran saintifik atau model koperatif } \\
\text { lainnya }\end{array}$ \\
\hline 4 & $\begin{array}{l}\text { Langkah Pembelajaran } \\
\text { dari 8 guru sudah menerapkan pembelajaran } \\
\text { pendekatan } \\
\text { pembelajaran koperatif lainnya }\end{array}$ \\
\hline 5 & Sumber dan Media Pembelajaran & 8 & $\begin{array}{l}\text { Buku menjadi satu-satunya sumber belajar. } \\
\text { Media masih terabaikan untuk 8 guru }\end{array}$ \\
\hline
\end{tabular}




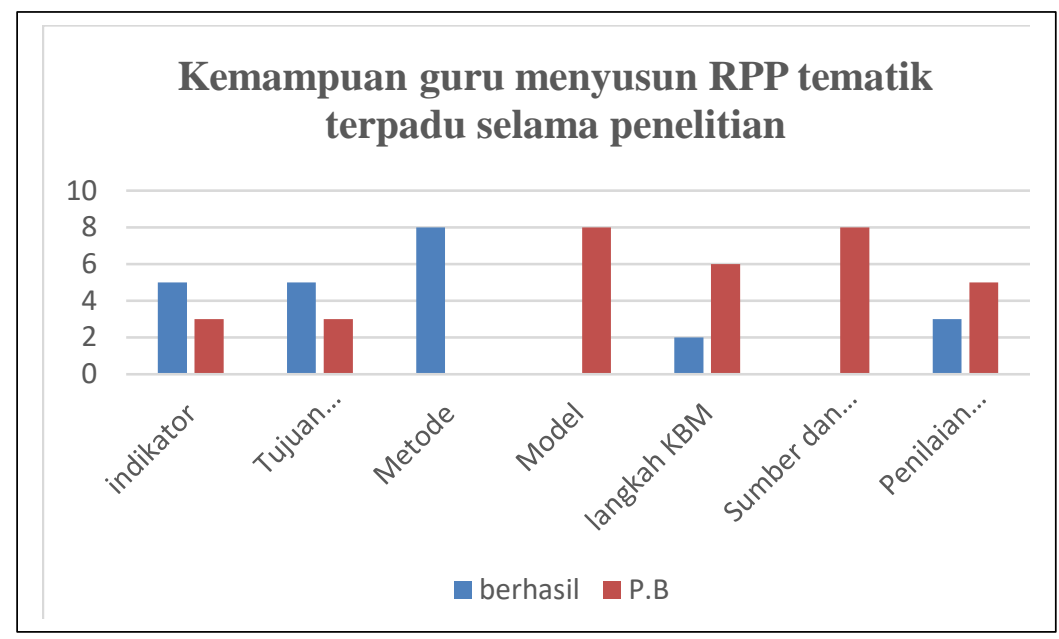

\section{Gambar 2. Diagram kemampuan guru menyusun RPP tematik terpadu selama penelitian}

Berdasarkan data di atas terlihat jelas bahwa kompetensi guru dalam menyusun RPP tematik terpadu berbeda-beda. Kemampuan guru dalam menyusun RPP tematik terpadu berdasarkan data di atas secara rinci dipaparkan sebagai berikut:

1. Kesulitan mengembangkan indikator, 5 dari 8 atau sekitar $62,5 \%$ berhasil mengembangkan idiikator sesuai Taksonomi Bloom dari tingkatan yang rendah ke yang tinggi sesuai tingkatan kelas, karateristik peserta didik untuk tiap muatan pelajaran dan sudah ada unsur HOTS (higher order thinking skills).3 guru atau sekitar 37,5\% masih perlu bimbingan (P.B).

2. Kesulitan merumuskan tujuan pembelajaran, dari 8 guru, 5 sudah berhasil merumuskan tujuan pembelajaran dengan mencantumkan unsur ABCD (Audience, Behaviour, Condition, dan Degree) atau sekitar 62,5\% dan perlu bimbingan sebanyak 3 guru atau sekitar $37.5 \%$.

3. Untuk metode pembelajaran pada umumnya semua guru sudah mampu menentukan bahkan menerapkannya dalam pembelajaran. berhasil atau 100\% (8 orang)

4. Penerapan model pembelajaran baik saintifik maupun model pembelajaran koperatif lainya semua guru masih perlu bimbingan pada kegiatan inti.

5. Langkah-langkah kegiatan pembelajaran khususnya pada kegiatan inti 2 guru berhasil atau sekitar 25\% berrhasil menuangkannya dalam RPP tetapi juga menerapkannya. 6 guru atau $75 \%$ masih perlu bimbingan lebih lanjut.

6. Kesulitan guru dalam melakukan penilaian autentik Kesulitan Menyusun instrument penilaian sikap dan membuat rubrik penilaian yang banyak menyebabkandari belum semua guru mampu menyusunnya. 3 dari 8 guru sudah berhasil menyusun instrumen dan rubrik penilaian sikap. Artinya masih ada 5 guru yang masih perlu bimbingan.Penilaian yang dilakukan guru selama ini lebih dominan pada penilaian pengetahuan.

\section{Faktor penghambat guru dalam penyusunan RPP tematik terpadu}

Faktor penghambat guru dalam menyusun RPP Tematik Terpadu pada implementasi kurikulum 2013 di sekolah antara lain:

\section{a. Minimnya pemahaman guru dalam menyusun RPP tematik terpadu}

Minimnya pemahaman guru dalam menyusun RPP Kurikulum 2013 sebagai dampak dari kurangnya kesempatan guru mengikuti kegiatan pelatihan, diklat ataupun workshop terkait penyususnan RPP. Tidak semua guru mendapat kesempatan yang sama untuk mengikuti pelatihan. Kalaupun ada hanya satu dua orang saja. Sayangnya merekapun tidak dapat mengimbasnya kepada guru yang lain sehingga kebermanfaatan ilmu yang diperoleh selama mengiktuti pelatihan tidak dapat dikembangkan. Termasuk lemahnya pengawasan dan pembinaan kepala sekolah dan pengawas sekolah. RPP yang dibuat guru hanya ditandatangani tanpa koreksi atau masukan bagi guru. Komponen-komponen RPP yang dirasa sulit oleh guru 


\section{ELEMENTARY : Jurnal Inovasi Pendidikan Dasar \\ Vol 2. No. 1, Januari 2022 P-ISSN : 2774-8014, e-ISSN : 2774-7034}

dalam menyusun RPP antara lain komponen indikator, tujuan, model dan metode, langkahlangkah pembelajaran, serta komponen penilaian.

\section{b. Ketersediaan waktu}

Ketersediaan waktu menjadi salah satu alasan yang turut mempengaruhi guru dalam menyusun RPP.Banyaknya tugas sekolah menjadi salah satu alasan guru yang cukup menyita waktu guru, sehingga dengan alasan ini guru tidak menyusun RPP. Kesibukan guru dalam menyiapkan tugas sekolah seperti menyusun prota, prosem, melakukan anaisis terhadap hasil belajar peserta didik, melaksanakan kegiatan ulangan tengah semester maupun ulangan akhir semeter, mengolah hasil belajar, pengisian raport, menyiapkan perangkat pembelajaran, membuat jurnal pembelajaran cukup menyita waktu sehingga dalam menyusun RPP belum terkondisikan dengan baik, dan inilah yang menjadi alasan guru untuk tidak menyusun RPP.

\section{c. Rendahnya motivasi serta komitmen guru}

Rendahnya motivasi serta komitmen guru dalam mengembangkan kompetensinya berdampak pada rendahnya hasil belajar peserta didik. Untuk itu guru dalam menerapkan pembelajaran interaktif, efektif, kreatif dan menyenangkan, guru perlu mengembangkan kompetensinya dan memotivasi dirinya sendiri sebagai guru yang profesional.

\section{d. sarana prasarana yang tidak memadai}

Ketersediaan sarana prasarana sebagai penunjang pembelajaran juga menjadi perhatian kepala sekolah sebagai pemimpin sekolah dalam menunjang tugas pokok guru di sekolah. Tidak hanya ketersediaan buku teks pelajaran, alat- alat teknologi seperti komputer atau leptoppun dapat membantu meringankan tugas guru dalam menyusun RPP tetapi juga dalam melaksanakan pembelajaran berbasis IT. Guru diera inipun seharusnya sudah melek teknologi sehingga pembelajaran berbasis teknologi dapat diterapkan di kelas dengan baik.

\section{e.Kemampuan guru dalam mengoperasikan teknologi informasi}

Guru diera inipun seharusnya sudah melek teknologi sehingga dalam menyusun RPP guru tidak lagi menuangkan dalam tulisan tangan tetapi dapat diketik menggunakan komputer, mengingat komponen RPP yang disusun secara tematik terpadu dari beberapa muatan pelajaran. Hal ini untuk meringankan beban guru yang cukup banyak sehingga tidak ada alasan bagi guru tidak memiliki RPP.

4. Upaya mengatasi kesulitan guru dalam penyusunan RPP tematik Terpadu Beberapa upaya yang dilakukan untuk mengatasi kesulitan guru dalam menyun RPP Tematik terpadu antara lain:

a. Sesering mungkin mengikuti kegiatan pelatihan, workshop, atau diklat untuk meningkatkan kompetensi guru khususnya dalam penyusunan Rencana Pelaksanaan Pembelajaran Tematik Terpadu. Dengan seringnya guru mengikuti kegiatan pelatihan, diklat maupun workshop diharapkan guru mendapatkan informasi yang lebih dalam menyusun RPP tematik Terpadu.

b. Kolaborasi antara kepala sekolah, pengawas ataupun LPMP untum meakukan pembinaan internal yang intensif kelompok kerja guru (KKG) mini di sekolah.

c. Diskusi dengan guru lain di sekolah maupun melalui forum KKG dilakukan selama sekali dalam satu minggu atau sekali dalam satu bulan. Guru yang mendapatkan kesempatan mengikuti pelatihan diharapkan dapat mengimplmentasikan ilmunya kepada guru yang lain (tutor sebaya).

d. Kersediaan waktu yang cukup. Guru diharapkan dapat memaksimalkan waktunya agar penyusunan RPP dengan tidak mengabaikan tugas sekolah lainnya.

e. Ketersediaan sarana prasarana. Sebagai penunjang pembelajaran di sekolah, guru harus ditunjang dengan sarana yang memadai. Jika tidak tersedia di sekolah, sebagai guru yang professional dapat mengupayakan secara mandiri apalagi guru yang sudah memiliki sertifikasi. f. Memiliki motivasi dan komitmen yang tinggi. Segalanya akan berjalan dengan baik ketika guru tersebut memiliki motivasi dan komitmen yang tinggi dalam menjalankan tugasnya.

g. Memiliki kemampuan menggunakan teknologi. Dengan kemampuan teknologi yang memadai, guru dapat memanfaatkan teknologi yang ada untuk mencari informasi yang dibutuhkan terkait penyusunan RPP 


\section{ELEMENTARY : Jurnal Inovasi Pendidikan Dasar Vol 2. No. 1, Januari 2022 P-ISSN : 2774-8014, e-ISSN : 2774-7034}

h. Guru seharusnya aktif dalam mencari informasi diberbagai media cetak maupun elektronik terkait dengan masalah pembelajaran termasuk menyusun RPP tematik terpadu.

\section{Pembahasan}

Berdasarkan hasil penelitian yang dilakukan melalui wawancara kepada kepala sekolah, pengawas, guru, observasi dan pengecekan dokumen sebelum dan selama penelitian dilakukan terkait kesulitan guru dalam menyusun RPP tematik Terpadu, ditemukan RPP yang dimilliki guru adalah hasil adopsi baik dari buku tetapi juga melalui observasi terhadap dokumen RPP dan pengecekan dokumen lain yang relevan dapat dikatakan belum maksimal. Kesulitan guru dalam menyusun RPP sebagaimana sudah disampaikan pada uraian sebelumnya bahwa kesulitan guru dalam menyusun RPP disebabkan guru belum mampu mengembangkan komponen-komponen RPP secara mandiri seperti menentukan indikator, tujuan pembelajaran, pemilihan metode dan model pembelajaran yang tepat, mengaplikasikan pembelajaran tematik terpadu dengan pendekatan saintifk, juga dalam memilih dan menetukan sumber belajar sesuai materi ajar dan mengembangakan instrumen penilaian. Kesulitan guru dalam menyusun RPP tematik terpadu dipaparkan sebagi berikut:

\section{Kesulitan guru dalam menyusun RPP Tematik Terpadu}

Hasil penelitian yang dilakukan melalui wawancara kepada kepala sekolah, pengawas, guru, dan didukung oleh hasil observasi dan pengecekan ditemukan 8 dari 8 guru mengalami kesulitan dalam mengembangkan indikator pembelajaran dengan menggunakan kata kerja operasional (KKO). Ketidakpahaman guru dalam mengembangkan indikator berawal dari ketidaktahuan guru dalam menganalisis kompetensi dasar kemudian merumuskannya menggunakan kata kerja operasional (KKO) mengakibatkan guru menjadi kesulitan menentukan indikator. Indikator merupakan penanda pencapaian kompetensi dan sebagai arah pencapaian tujuan pembelajaran sudah seharusnya dirumuskan dengan baik menggunakan kata kerja opereasional (KKO) sesuai tingkatannya dari yang termudah yaitu C1-C6 menurut Taksonomi Bloom. Hal ini sejalan dengan pendapat yang dikemukakan oleh Ernawati (2017: 52) bahwa beberapa guru belum mampu menggunakan kata kerja operasional yang sesuai dengan kompetensi yang diukur. Melalui pembinaan yang diberikan peneliti melalui forum diskusi kelompok kerja guru mini di sekolah selama peneliti melakukan penelitian di sekolah,5 guru diantaranya sudah mampu menentukan indikator menggunakan kata kerja opersional dan disusun secara sistematis dari yang mudah ke yang sulit (C1-C6). Sesuai dengan pendapat dari Prastowo (2019:35) bahwa indikator dirumuskan dengan menggunakan kata kerja oprasional mencakup dua hal yaitu tingkat kompetensi dan materi yang menjadi pencapaian kompetensi.

Berdasarkan kedua pendapat di atas dapat disimpulkan bahwa indikator pembelajaran sebagai penunjuk arah kemana pembelajaran ini akan bermuara, berhasil atau tidaknya suatu pembelajaran tidak terlepas dari peran indikator itu sendiri. Itu sebabnya sebagai guru dituntut kompetensinya dalam melakukan analisis terhadap kompetensi dasar, kemudian merumuskannya dalam beberapa indikator yang tersusun secara sistematis menggunakan kata kerja operasional (KKO) mencakup dua hal yaitu tingkat kompetensi dan materi yang menjadi pencapaian kompetensi.

Tujuan pembelajaran merupakan suatu perilaku dari hasil yang diharapkan terjadi, dimiliki, dikuasai oleh peserta didik setelah mengikuti proses belajar mengajar. Dengan kata lain tujuan pembelajaran merupakan arah yang hendak dituju atau dicapai dari suatu rangkaian aktivitas pembelajaran. Tujuan pembelajaran dirumuskan dalam bentuk perilaku yang spesifik, aktual dan terukur. Tujuan pembelajaran mengacu pada kompetensi dasar dan indikator pencapaian kompetensi yang harus dicapai dalam pembelajaran. Kemampuan guru SD Inpres 48 Inggramui distrik Manokwari Barat sebelum mendapatkan pembinaan, tergolong rendah dalam merumuskan tujuan pembelajaran. Hasil observasi dokumen RPP tematik terpadu yang dimiliki guru pada komponen tujuan pembelajaran mencakup 2 unsur dari 4 unsur yang persyaratkan dalam merumuskan tujuan pembelajaran yakni Audience, Behaviour. Semetinya dalam merumuskan tujuan pembelajaran harus memenuhi 4 unsur yaitu Audience, Behaviour, 


\section{ELEMENTARY : Jurnal Inovasi Pendidikan Dasar Vol 2. No. 1, Januari 2022 P-ISSN : 2774-8014, e-ISSN : 2774-7034}

Condition, dan Degree (ABCD). Setelah mendapatkan pembinaan melalui forum diskusi kelompok kerja guru mini di sekolah, 5 dari 8 guru dianggap sudah mampu merumuskan tujuan pembelajaran dengan mencantumkan 4 unsur yang menjadi syarat perumusan tujuan pembelajaran kurikulum 2013 yaitu unsur ABCD dan HOTS (higher order thinking skills). 3 guru masih kesulitan dalam merumuskan tujuan pembelajaran. Kesulitan ini disebabkan karena guru belum mampu mengembangkan indikator pembelajaran sebagaimana disampaikan oleh Prastowo (2015: 190) bahwa pada dasarnya merumuskan tujuan pembelajaran tidaklah begitu sulit jika sudah paham dan menguasai cara mengembangkan indikator. Melalui rumusan tujuan, guru dapat memproyeksikan apa yang harus dicapai oleh siswa setelah berakhir proses pembelajaran. Kyriacou (2011: 44) tujuan pembelajaran merupakan upaya perubahan tingkah laku siswa yang berlangsung sebagai akibat dari keterlibatannya dalam sebuah pengalaman pendidikan.

Dari dua pendapat di atas dikatakan bahwa dalam merumuskan tujuan pembelajaran sesungguhnya tidaklah sulit jika guru tersebut sudah mampu mengembangkan indikator pencapaian kompetensi dengan baik dan benar.Karena dengan merumuskan tujuan pembelajaran guru dapat memproyeksikan apa yang harus dicapai oleh siswa setelah berakhir proses pembelajaran.

Metode adalah suatu cara yang dipergunakan untuk mencapai tujuan yang telah ditetapkan. Metode pembelajaran digunakan oleh guru untuk mewujudkan suasana belajar dan proses pembelajaran agar peserta didik mencapai kompetensi dasar atau seperangkat indikator yang telah ditetapkan Rusman (2011:6). Sedangkan model pembelajaran sangat erat kaitannya dengan gaya belajar siswa dan gaya mengajar guru. Melalui model pembelajaran, guru dapat membantu siswa untuk mendapatkan informasi, keterampilan, cara berpikir, dan mengekpresikan idenya. Suprihatiningrum (2013:145) mengemukakan bahwa model pembelajaran merupakan suatu rancangan yang di dalamnya menggambarkan sebuah proses pembelajaran yang dapat dilaksanakan oleh guru dalam mentransfer pengetahuan maupun nilainilai kepada siswa. Lebih lanjut, Kurniasih \& Sani (2014: 64) mengemukakan bahwa dalam pembelajaran banyak model pembelajaran yang dapat digunakan untuk menuntut siswa menjadi aktif dalam kegiatan belajar mengajar yaitu discovery learning, problem based learning, project based learning, dan cooperative learning. Model pembelajaran tersebut berusaha membelajarkan siswa untuk mengenal masalah, merumuskan masalah, mencari solusi atau menguji jawaban sementara atas suatu masalah/pertanyaan dengan melakukan penyelidikan (menemukan fakta melalui penginderaan), pada akhirnya dapat menarik kesimpulan dan menyajikannya secara lisan maupun tulisan.

Paparan di atas dapat disimpulan bahwa baik metode maupun model pembelajaran merupakan upaya yang digunakan untuk menciptakan pembelajaran menjadi lebih interaktif melalui berbagai kegiatan pembelajaran yang menuntut keaktivan dari peserta didik serta melatih keterampilan berpikir tingkat tinggi HOTS melalui berbagai kegiatan pembelajaran yang dirancang guru seperti pemecahan masalah, melakukan penyelidikan kemudian menarik kesimpulan dari apa yang mereka kerjakan yang kemudian akan dikomunikasikan dalam bentuk tulisan maupun lisan.Kondisi ini sepenuhnya belum dilakukan guru di SD Inpres 48 Inggramui.Pada saat wawancara semua guru menyampaikan hal yang sama bahwa sesungguhnya untuk metode pembelajaran semua guru sudah mengerti bahkan beberapa dari mereka sudah menerapkannya dalam pembelajaran.

Umumnya metode yang diterapkan guru antara lain ceramah, tanya jawab, diskusi dan pemberian tugas. Namun masih ada juga hanya menggunakan metode ceramah pada saat melakukan proses belajar mengajar. Berbeda dengan model pembelajaran semuanya mengaku belum tahu apa saja model pembelajaran dan bagaimana sintak atau langkah-langkanya.Dari pembinaan yang diberikan peneliti, untuk metode pembelajaran semua guru sudah memahaminya dengan baik dan sudah diterapkan dalam pembelajaran. Untuk model pembelajaran guru masih kesulitan dan membutuhkan pembinaan yang lebih intensif baik dari kepala sekolah maupun pengawas. 
Langkah-langkah pembelajaran terbagi menjadi tiga bagian yaitu kegaiatan pendahuluan, inti dan penutup. Pada kegiatan pendahuluan dan kegiatan penutup ketika wawancara dan pengecekan dokumen 2 dari 8 guru sudah dapat mengaplikasikannya walau belum maksimal. Yang menjadi sulit bagi semua guru adalah pada kegiatan inti, dimana pada kegiatan inti guru harus merancang kegiatan dengan menggunakan model atau pendekatan yang sesuai dengan karateristik peserta didik, lingkungan sekolah, kesesuaian dengan materi dan tentunya sesuai juga dengan kompetensi guru itu sendiri. Implemntasi kurikulum 2013 memberikan keleluasaan bagi guru dalam mendesain pembelajaran menggunakan model atau pendekatan pembelajaran. Pendekatan saintifik menjadi salah satu pendekatan pembelajaran yang disarankan oleh kurikulm 2013. Dalam pelaksanaannya seringkali guru kesulitan menerapkannya karena kurikulum 2013 dilakukan berbasis tematik terpadu, dimana dalam pelaksanaannya tidak berdiri sendiri seperti pada kurikulum sebalumnya. Terjadi penggabungan beberapa kaompetensi dasar dari beberapa muatan pelajaran yang dikemas dalam bentuk tema. Pada kegiatan inti kurikulum 2013 guru kesulitan untuk mengaitkan perpindahan materi yang satu edngan materi yang lain. Sehingga menurut pengakuan para guru, meskipun RPPnya bentuknya RPP tematik tapi dalam pelaksanaannya masih seperti kurikulum sebelumnya.

Hal ini sejalan dengan penelitian yang dilakukan oleh Nurhaliza (2019) yang menunjukkan bahwa dalam menyusun langkah-langkah pembelajaran guru belum sepenuhnya memahami sintak dari model dan metode yang digunakan dan juga kesulitan dalam menyusun kegiatan inti guru menerapkan pendekatan berbasis saintifik 5M (mengamati, menanya, mengumpulkan informasi, mengkomunikasikan). Sehingga kebanyakan guru hanya mengambil langkah-langkah pembelajaran dari buku guru tanpa adanya pengembangan sesuai kebutuhan peserta didik dan kondisi sekolah karena keterbatasan pemahaman dan waktu yang tersedia dalam menyusun kegiatan yang maksimal. Hal senada disampaikan oleh Prastowo (2015:341) bahwa pendekatan pembelajaran saintifik memiliki karakteristik yang berbeda dengan pendekatan lainnya. Guru belum terbiasa menyusun dan menerapkan pembelajaran dengan pendekatan saintifik sehingga pembelajarannya belum sepenuhnya menerapkan pendekatan saintifik pada kegiatan inti. langkah-langkah pendekatan saintifik dalam pembelajaran yang memunculkan $5 \mathrm{M}$ (mengamati, menanya, mengumpulkan informasi, mengkomunikasikan).

Berdasarkan kedua pendapat di atas dapat disimpulkan bahwa untuk memaksimalkan proses belajar mengajar, guru harus terbiasa menyusun dan mengimlementasikan pendekatan saintifik dalam proses belajar mengajar melalui kegiatan mengamati, menanya, mengumpulkan informasi dan mengkomunikasikan.

Segala sesuatu yang ada dilingkungan sekitar yang dimanfaatkan untuk mengoptimalkan proses belajar mengajar dikenal dengan sebutan sumber belajar. Pemanfaatan sumber belajar dimaksukan untuk memudahkan peserta didik dalam memahami materi ajar sesuai dengan tujuan yang diharapkan. Trianto (2010:203) menyebutkan bahwa sumber belajar mencakup semua sumber yang digunakan siswa agar terjadi perilaku belajar. Peranan sumber belajar yaitu mentransmisi informasi kepada siswa tentang dunia disekitar mereka dan membuat pembelajaran lebih bermakna.Hal senada disampaikan Soeharto dkk (2003:73) Sumber belajar dapat berupa buku teks, media cetak seperti majalah dan koran, media elektronik berupa radio dan televisi, narasumber dan lingkungan sekitar baik keluarga, sekolah atau masyarakat. Sumber belajar, baik elektronik maupun non elektronik dapat ditemukan kapanpun dan dimanapun sehingga memudahkan siswa dalam belajar.

Untuk mengefektifkan proses belajar mengajar dan agar pesan dapat tersampaikan dengan baik dibutuhkan media. Munadi (2008:7) mendefinisikan bahwa media pembelajaran dapat dipahami sebagai segala sesuatu yang dapat menyampaikan dan menyalurkan pesan dari sumber secara terencana sehingga tercipta lingkungan belajar yang kondusif dimana penerimanya dapat melakukan proses belajar secara efisien dan efektif. Pendapat yang sama yang dikemukakan oleh Sadiman, dkk (2010:6) bahwa media merupakan segala sesuatu yang dapat digunakan untuk menyalurkan pesan dari pengirim ke penerima sehingga dapat 


\section{ELEMENTARY : Jurnal Inovasi Pendidikan Dasar Vol 2. No. 1, Januari 2022 P-ISSN : 2774-8014, e-ISSN : 2774-7034}

merangsang pikiran, perasaan, perhatian dan minat siswa sedemikian rupa sehingga proses belajar terjadi.Selanjutnya Asyhar (2012:8) mengungkapkan bahwa media pembelajaran adalah segala sesuatu yang dapat menyampaikan atau menyalurkan pesan dari suatu sumber secara terencana, sehingga terjadi lingkungan belajar kondusif dimana penerimanya dapat melakukan proses belajar secara efisien dan efektif.

Berdasarkan paparan di atas dapat digaris bawahi bahwa sumber belajar dan media pembelajaran merupakan sarana pendukung dalam proses belajar mengajar yang digunakan guru untuk menyampaikan pesan selaian itu dengan sumber belajar yang variative didukung media pembelajaran yang sesuai diyakini akan mengefektifkan dan mengoptimalkan pembelajaran yang dikelola guru.

Bagian yang tak terpisahkan dalam kegiatan pembelajaran adalah penilaian. Penilaian dalam penerapan kurikulum 2013 dikenal dengan penilaian Autentik. Penilaian autentik merupakan penilaian yang mencerminkan dunia nyata (pembelajaran kontekstual) yang menggunakan banyak metode dan bersifat konprehensif, holistic, yang melibatkan berbagai ranah kompetansi (pengetahuan, keterampilan dan sikap) Muclisch,(2011:3). Instrument penilaian autentik merupakan komponen terakhir dalam RPP yang juga paling banyak dikeluhkan guru. Keluhan guru terkait instrumen penilaian pada kurikulum 2013 dikarenakan terlampau banyak. Terutama guru dengan kemampuan teknologi yang terbatas, hal ini menjadi sangat sulit dilakukan. Hasil penelitian menunjukan bahwa 3 dari 8 guru berhasil menyusun instrument penilaian autentik setelah mendapatkan bimbingan melalui forum diskusi guru dalam kelompok kerja guru (KKG) mini di sekolah selama penelitian dilakukan. Kesulitan guru dalam mengembangkan instrument penilaian autentik mengakibatkan seringkali guru hanya melakukan penilaian pengetahuan saja.

Penilaian autentik pada kurikulum 2013 mencakup penilaian sikap (afektif), pengetahuan (kognitif) dan keterampilan (psikomotorik). Penilaian Sikap terbagi 2 yakni sikap spiritual dan sikap sosial. Aspek-aspek yang dinilai pada penialan sikap spiritual dan sikap sosial berbeda. Intrumen penilaian sikap seperti instrument penilaian melalui observasi, penilaian diri (self assessment), penilaian teman sejawat (peer evalution) dan jurnal. Penilaian observasi dilakukan setiap hari baik selama proses belajar mengajar di kelas maupun diluar kelas, jurnal guru harus dicatat setiap peristiwa yang terjadi selama di sekolah, penilaian diri dan teman sejawat dilakukan sekali menjelang penilaian akhir semester. Banyaknya instrumen yang yang harus disiapkan guru membuat guru lebih memilih untuk melakukan penilaian pengetahuan, sesekali penilaian keterampilan dan yang jarang dilakukan guru adalah penilaian sikap.

Selain membuat instrument penilaian, guru juga mengeluhkan pembuatan kriteria dan rubriknya. Untuk memenuhi tugas administrasinya guru lebih memilih mengkopi paste yang sudah ada di buku maupun internet tanpa adaptasi.

\section{Faktor penghambat guru dalam penyusunan RPP tematik terpadu}

Faktor penghambat guru dalam menyusun RPP Tematik Terpadu antara lain; (a) kurangnya keterlibatan dalam kegiatan sosialisasi, pelatihan, diklat, workshop, supervise, KKG gugus maupun KKG mini menjadi pemicu rendahnya pemahaman guru dalam menyusun RPP Kurikulum 2013.Hal ini sesuai dengan pendapat dari Krisdiana dan Setyaningsih (2014) menyatakan bahwa kurangnya pelatihan atau workshop yang diikuti oleh guru dapat menjadi faktor penyebab pemahaman dan implementasi kurikulum 2013 masih kurang. (b) Kurang tersedianya waktu. Berdasarkan penelitian yang dilakukan oleh Ayuriyani (2015) kekurangan waktu dalam pembuatan RPP dapat diakibatkan karena banyaknya tugas yang harus dikerjakan oleh guru, sehingga waktu yang digunakan untuk menyusun RPP tidak optimal hal tersebut mengakibatkan guru tidak menyusun RPP sebelum mengadakan pembelajaran. (c)Rendahnya motivasi diri dan komitmen guru berdampak pada minimnya pemahaman guru terhadap penyusunan RPP tematik terpadu. (d); sarana prasarana penunjang kegiatan sekolah yang kurang memadai turut mempengaruhi semangat guru dalam menyiapkan RPP.(e) kemampuan 
dalam memanfaatkan teknologi yang masih rendah menyebabkan guru kesulitan menyusun RPP tematik terpadu terlebih kepada guru yang memasuki masa purna tugas.

\section{Upaya mengatasi kesulitan guru dalam penyusunan RPP tematik Terpadu}

Beberapa upaya yang dilakukan untuk mengatasi kesulitan guru dalam menyun RPP Tematik terpadu antara lain: (a) Mengikutsertakan guru dalam berbagai kegiatan sosialisasi, pelatihan, workshop, atau diklat penyusunan RPP tematik terpadu,(b) mengikuti pembinaan melalui kegiatan supervise maupun diskusi di KKG Gugus atau KKG mini lebih intensif dilakukan oleh kepala sekolah maupun kolaborasi dengan pengawas dan LPMP. (c) Menyiapkan sarana prasarana yang menunjang aktivitas guru dalam pembelajaran termasuk menyiapkan RPP tematik terpadu termasuk internet di sekolah, (d)guru aktif mencari informasi dari berbagai media cetak maupun elektronik (e) kolaborasi kepala sekolah dan pengawas lebih diintensifkan, (3) guru harus memiliki motivasi dan komitmen yang tinggi, (f) kemampuan IT guru harus baik agar meringankan pekerjaan guru.

\section{KESIMPULAN}

Berdasarkan hasil penelitian dan pembahasan diatas, maka dapat disimpulkan bahwa: Guru SD Inpres 48 Inggramui distrik Manokwari Barat dalam menyusun rencana pelaksanaan pembelajaran tematik terpadu dapat dikatakan tergolong rendah. Probematika guru dalam menyusun RPP tematik terpadu adalah mengembangkan indicator pembelajaran, merumuskan tujuan pembelajaran, menentukan metode dan model pembelajaran, menentukan Langkahlangkha pembelajaran khususnya pada kegiatan inti, menentukan sumber dan media pembelajaran serta mengembangkan instrumen penilaian keterampilan dan sikap. Beberapa factor yang ditenggarai menjadi pemicu rendahnya kompetensi guru dalam menyusun RPP tematik terpadu antara lain: kurangnya kesempatan guru dalam mengikiti sosialisasi, pelatihan, diklat, yang di lakukan pemerintah, tetapi juga kegiatan workshop dan bentuk pembinaan lainnya yang dilakukan sekolah seperti kegiatan supervisi, mengikuti KKG gugus dan KKG mini di sekolah yang tidak intensif dilakukan serta minimnya waktu, motivasi, komitmen dan kemampuan menggunakan teknologi yang rendah juga turut andil dalam menciptakan kesulitan guru dalam menyusun RPP tematik terpadu.

upaya yang dilakukan untuk mengatasi kesulitan guru dalam menyun RPP Tematik terpadu antara lain: (a) Mengikutsertakan guru dalam berbagai kegiatan sosialisasi, pelatihan, workshop, atau diklat penyusunan RPP tematik terpadu,(b) mengikuti pembinaan melalui kegiatan supervise maupun diskusi di KKG Gugus atau KKG mini lebih intensif dilakukan oleh kepala sekolah maupun kolaborasi dengan pengawas dan LPMP. (c) Menyiapkan sarana prasarana yang menunjang aktivitas guru dalam pembelajaran termasuk menyiapkan RPP tematik terpadu termasuk internet di sekolah, (d)guru aktif mencari informasi dari berbagai media cetak maupun elektronik (e) kolaborasi kepala sekolah dan pengawas lebih diintensifkan, (3) guru harus memiliki motivasi dan komitmen yang tinggi, (f) kemampuan IT guru harus baik agar meringankan pekerjaan guru. Hasil penelitian yang dilakukan di SD Inpres 48 Inggramui Distrik Manokwari Barat menunjukkan bahwa beberapa guru sudah ada yang menunjukkan progress yang baik walaupun belum maksimal untuk beberapa komponen RPP, namun masih terdapat guru yang memang benar-benar memerlukan perhatian khusus dari kepala sekolah maupun pengawas sekolah.

\section{DAFTAR PUSTAKA}

Aryani, Siswi Dwi. 2015. Hambatan Guru Dalam Perencanaan, Pelaksanaan Dan Penilaian Pembelajaran Kompetensi Keahlian Multimedia Pada Penerapan Kurikulum 2013 Di SMK Se Daerah Istimewa Yogyakarta. Yogyakarta: Universitas Negeri Yogyakarta.

Arum Mawar Kinarsih. 2019. Optimalisasi Kompetensi Guru Dalam Penyusunan Rencana

Pelaksanaan Pembelajaran. Jurnal Ilmiah DIDAKTIKA 20 (1) 69- 82

Asyhar. 2012. Kreatif Mengembangkan Media Pembelajaran. Jakarta: Referensi. 
Ernawati. 2017. Analisis Kesulitan Guru Dalam Merancang Rencana Pelaksanaan Pembelajaran Mata Pelajaran Fisika Berdasarkan Kurikulum 2013 Di Kota Banda Aceh". Jurnal Pendidikan Sains Indonesia (Indonesian Journal of Science Education) 5,(2) 49-56.

Fathurrohman M. dan Sulistyorini. 2012. Belajar Pembelajaran Membantu Meningkatkan Mutu Pembelajaran sesuai Standar Nasional. Yogyakarta : Teras

Iman S, Wamugi dan A.Nurhamidi. 2019. Kemampuan Guru MI yang Bersertifikat Pendidik dalam Menyusun Rencana Pembelajaran (Kasus Kota Pekalongan). Jurnal Penelitian, $10(1$,

Kemendikbud. Permendikbud Nomor 81 A Tahun 2013. Permendikbud Nomor 81A Tahun 2013 Tentang Implementasi Kurikulum Pedoman Umum Pembelajaran. Jakarta: Kementerian Pendidikan dan Kebudayaan RI. 2013.

Kyriacou, C. 2011. Effective Teaching: Theory and Practice. Bandung: Nusa Media.

Kurniasih \& Sani, 2014 Kurniasih, Imas. \& Sani, Berlin. 2014. Implementasi Kurikulum 2013: Konsep \& Penerapan. Surabaya: Kata Pena.

Muclisch. 2011. Kendala Guru Dalam Penyelenggaraan Penilaian Sikap. Jurnal Pendidikan Kimia Undiksha 2( 2) 69-74.

Munadi, Yudhi. 2008. Penggunaan Media Audio Visual Untuk Meningkatkan Pemahaman Konsep Siswa Di Sekolah Dasar. JPGSD 01(02) 0-216

Nurhaliza Siti. 2019. Identifikasi Kesulitan Dalam Menyusun RPP Kimia Kurikulum 2013 Oleh Guru Pada Tingkat Madrasah Aliyah Pidie Jaya. Skripsi. Fakultas Tarbiyah Dan Keguruan. Universitas Islam Negeri Ar-Raniry. Banda Aceh.

Peraturan Pemerintah Nomor 19 Tahun 2005 tentang Standar Nasional Pendidikan, Jakarta: Depdiknas, 2005.

Prastowo A. 2015. Menyusun Reancana Pelaksanaan Pembelajaran (RPP) Tematik Terpadu Impelementasi Kurikulum 2013 untuk SD/MI. Jakarta: Prenada Media Grup

Prastowo A. 2019. Analisis Pembelajaran Tematik Terpadu. Jakarta: Kencana.

Rusman. 2011. Model-Model Pembelajaran Mengembangkan Profesionalisme Guru. Jakarta. Raja Grafindo Persada.

Sugiyono. 2016. Metode Penilitian Pendidikan Pendekatan Kuantitatif, Kualitatif, dan R\&D, Bandung. Alfa Beta

Suprihatiningrum Jamil. 2013. Strategi Pembelajaran : Teori \& Aplikasi. Yogyakarta : ArRuzz Media

Sadiman, dkk. 2010. Media Pembelajaran Pengertian, Pengembangan, dan Pemanfaatannya. Jakarta: PT Raja Grafindo Persada.

Trianto. 2010. Model pembelajaran terpadu: konsep, strategi dan implementasinya dalam kurikulum tingkat satuan pendidikan (KTSP). Jakarta: PT Bumi Aksara. 